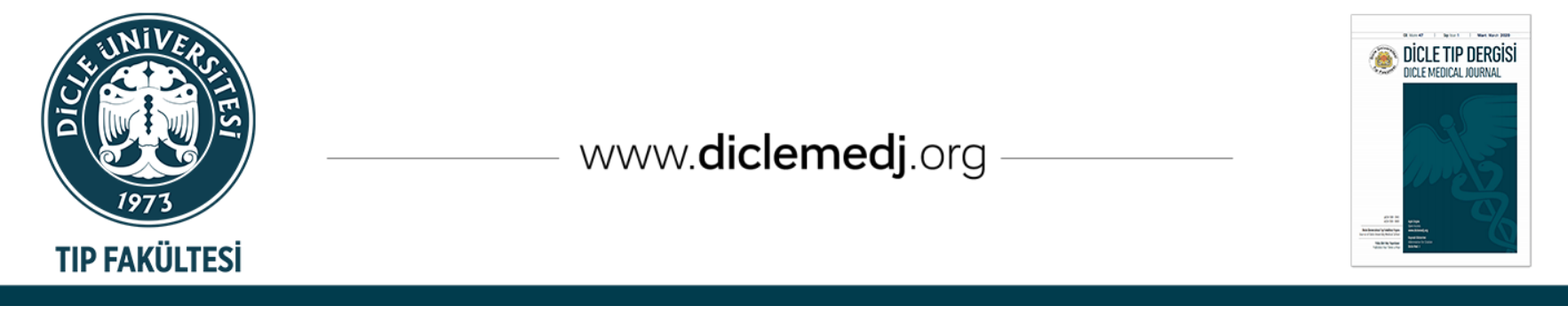

Original Article / Özgün Araştırma

\title{
Evaluation of Platelet Indices in Diabetic Patients with Myocardial Bridges
}

\author{
Mehmet Inanir iD 1 \\ 1 Mehmet Inanir; Bolu Abant Izzet Baysal University, Medical Faculty, Cardiology Department, Bolu, Turkey
}

Received: 06.03.2020; Revised: 05.04.2020; Accepted: 06.04.2020

\begin{abstract}
Objectives: Myocardial bridges (MB) are a congenital anomaly in which part of the epicardial coronary artery is intramuscular, known as the presence of myocardium, which causes narrowing of the artery during heart contraction. We aimed to evaluate hemogram parameters (especially platelet indices) in diabetic patients with myocardial bridges.

Methods: We reviewed angiograms performed between May 2017 and August 2019 at Bolu Abant Izzet Baysal University Medical Faculty Hospital. After appropriate exclusions, diabetic patients were divided into groups with myocardial bridges and normal coronary artery groups. A total of 124 patients were included in the study and hemogram parameters of these two groups were compared. Kolmogorov Smirnov test was used to examine the normality of variables. Data were compared using univariate tests including independent samples t-test, Mann-Whitney U-test and chi-square test.
\end{abstract}

Results: Compared to control group PDW (17.7 (15.9-19.5) vs.17.4 (16.2-18.9) \% p=0.047), MPV (8.3 (6.6-11.4) vs. 7.5 (6.6-8.7) Fl p<0.001), PCT (0.2 (0.16-0.25) vs. 0.18 (0.13-0.24) p=0.004), and Neutrophil-Lymphocyte Ratio (NLR) (1.71 $(0.82-9.14)$ vs. $1.43(0.78-5.75) \mathrm{p}=0.036)$ were significantly higher in MB patients. There was no significant difference between the two groups in terms of other biochemical and hemogram values.

Conclusion: Common, simple and inexpensive platelet indices were found to be increased in myocardial bridge diabetic patients.

Keyword: Atherosclerosis, myocardial bridges, diabetes mellitus, platelet indices, inflammation. 


\section{Miyokardiyal Kas Bandı Olan Diyabetik Hastalarda Trombosit İndekslerinin Değerlendirilmesi}

Öz

Amaç: Miyokardiyal kas bandı, epikardiyal koroner arterin bir kısmının kalp kasılması sırasında arterin daralmasına neden olan miyokard varlığı olarak bilinen kas içi olduğu konjenital bir anomalidir. Miyokardiyal kas bandı olan diyabetli hastalarda hemogram parametrelerini (özellikle trombosit indeksleri) değerlendirmeyi amaçladık.

Yöntemler: Mayıs 2017-Ağustos 2019 tarihleri arasında Bolu Abant İzzet Baysal Üniversitesi Tıp Fakültesi Hastanesi'nde yapılan anjiyogramları gözden geçirdik. Uygun dışlamalardan sonra, diyabetik hastalar miyokardiyal kas bandı olan grup ve normal koroner arter gruplarına ayrıldı. Çalışmaya toplam124 hasta dahil edildi ve bu iki grubun hemogram parametreleri karşılaştırıldı. Değişkenlerin normalliğini incelemek için Kolmogorov Smirnov testi kullanıldı. Veriler bağımsız örneklem t-testi, Mann-Whitney U-testi ve ki-kare testi gibi tek değişkenli testler kullanılarak karşılaştırıldı.

Bulgular: Kontrol grubu ile klyaslandığında PDW (17.7 (15.9-19.5) vs.17.4 (16.2-18.9) \% p=0.047), MPV (8.3 (6.6-11.4) vs. 7.5 (6.68.7) Fl p<0.001), PCT (0.2 (0.16-0.25) vs. 0.18 (0.13-0.24) p=0.004) ve Nötrofil-Lenfosit Oranı (NLR) (1.71 (0.82-9.14) vs. 1.43 (0.785.75) $\mathrm{p}=0.036$ ) miyokardiyal kas bandı hastalarında anlamlı olarak daha yüksek bulundu. İki grup arasında diğer biyokimyasal ve hemogram değerleri açısından anlamlı fark yoktu.

Sonuç: Miyokardiyal kas bandı olan diyabetik hastalarda yaygın, basit ve ucuz trombosit indekslerinde artış olduğu bulundu.

Anahtar kelimeler: Ateroskleroz, miyokardiyal kas bandı, diabetes mellitus, trombosit indeksleri, inflamasyon.

\section{INTRODUCTION}

A myocardial bridge (MB) is a congenital anomaly $^{1}$ of the myocardium that covers the coronary artery, which causes the artery to narrow during systole ${ }^{2}$. MB, which is the most common congenital coronary anomaly, has a prevalence of less than 5\% following routine angiography ${ }^{3}$. MB was first identified in 17374; modern medicine has determined that $\mathrm{MB}$ accelerates atherosclerosis ${ }^{5}$. The condition is also more widespread in patients with coronary artery disease $(\mathrm{CAD})^{5}$. Feeding of the myocardium may be impaired by MB and may cause ischemia due to the shortening of the diastolic phase secondary to tachycardia in addition to the atherosclerosis induced by the bridge $^{5}$. MB may cause chest pain upon exertion, arrhythmias, dyspnea, left heart failure, coronary spasm, acute coronary syndromes, and even sudden cardiac death ${ }^{1}$. Various investigations have demonstrated that MB may lead to ischemia. MBs can be identified using several diagnostic techniques, such as computed tomography, magnetic resonance imaging, coronary angiography, intravascular ultrasound, and fractional flow reserve ${ }^{6,7}$. The gold standard for diagnosing MB is angiography that reveals a systolic milking effect produced by systolic compression of the intramyocardial segment $^{3}$. The prevalence of $\mathrm{MB}$ is higher in young patients with fewer comorbidities and stable $\mathrm{CAD}^{5}$. $\mathrm{MB}$ is associated with coronary endothelial dysfunction and the early stages of atherosclerosis ${ }^{8}$, and the atherosclerosis that develops proximal to the bridge results from shear stress 9 .

Diabetes mellitus (DM) is a complex cardiometabolic disease that occurs at a worldwide rate of approximately $8.5 \%{ }^{10}$. DM is associated with an increased prevalence of cardiovascular events ${ }^{11}$. The risk of cardiovascular disease (CVD) and death is two to three times higher in diabetics ${ }^{12}$. DM may have a key role in the progression of atherosclerosis in the proximal segment of $\mathrm{MB}^{13}$.

Platelets play a significant role in death-causing thrombosis and atherosclerosis ${ }^{14}$. Platelet height increases inflammation and is associated with atherosclerosis ${ }^{15}$. The mean platelet volume (MPV), platelet distribution width 
(PDW), and plateletcrit (PCT) derived from a complete blood count (CBC) are indices specific to platelet morphology and proliferation kinetics ${ }^{16}$. Studies have shown that there is a relationship between platelet indices and CAD ${ }^{17}$. Platelet indices may also aid in the diagnosis and prognosis of many diseases and conditions, such as CVD. Therefore, in this study, we aimed to evaluate the platelet indices in diabetic MB patients.

\section{METHODS}

\section{Patient Selection}

We reviewed angiograms performed between May 2017 and August 2019 at Bolu Abant Izzet Baysal University Medical Faculty Hospital. A Siemens Axiom Artis diagnostic device (Siemens Healthcare GmbH, Forchheim, Germany) was used to perform the coronary angiography. These procedures were carried out to identify ischemic heart disease based on clinical indications. The study was conducted in accordance with the ethical approval of the University Ethics Committee. (Date: 14/10/2019 Decision number: 2019/218). Two cardiologists who were blinded to the study's details visually evaluated the coronary angiography images recorded in a digital format to identify MB. Any patients diagnosed with MB were included in the study. The following baseline demographic data and clinical cardiovascular risk factors were obtained from the institution database and patient files: hypertension, dyslipidemia, DM, smoking or former smoking, a family history of CAD, weight, and height. There was no significant difference in demographic parameters between the MB patients and the control group with normal coronary angiography. The study excluded the following patients: participants with a history of chronic diseases, such as heart failure (ejection fraction $<50 \%$ ), liver or kidney failure, acute and chronic lung disease, or obstructive sleep apnea; chronic inflammation; previous coronary artery bypass grafting; any percutaneous coronary intervention; acute coronary syndrome; significant valve disease; atrial fibrillation; hypertension; autoimmune diseases; myocarditis; pericarditis; any active infection; cancer; hypo/hyperthyroidism; stroke; developmental or intellectual delays; delirium; dementia; electrolyte imbalances; and any hematological abnormality, including sickle cell anemia or thrombocytopenia; those currently being treated with antiplatelet/anticoagulant agents, steroids, or immunosuppressive therapy; and patients who were pregnant, current smokers, or were under 18 years of age.

\section{Statistical Analysis}

SPSS software was used for statistical analysis (SPSS 22.0 for Windows, IBM Co, Chicago, IL, USA). The distribution normality was determined by the Kolmogorov Smirnov test. Normal variables were compared with the T-test and expressed as mean \pm standard deviation. Mann Whitney U test was used for variables showing the abnormal distribution and expressed as median (IQR: interquartile interval). A chi-square test was used to compare nonparametric variables. A p-value lower than 0.05 was considered statistically significant.

\section{RESULTS}

All patients were diabetic. The diagnosis of DM was based on a previous history of DM. We enrolled 124 individuals including $62 \mathrm{MB}$ patients (mean age: 54 [range: 35-76] years) and 62 control participants (mean age: 57 [range: 44-77] years). The mean age, frequencies of sex, and body mass index were not significantly different between diabetic patients with MB and the control group. (Table I). 
Table I: General characteristics of the study groups

\begin{tabular}{|c|c|c|c|}
\hline Baseline characteristics & $\begin{array}{c}\text { Diabetic } \\
\text { Myocardial } \\
\text { Bridge Group } \\
\quad(n=62)\end{array}$ & $\begin{array}{l}\text { Control } \\
\text { Group } \\
(n=62)\end{array}$ & $P$ value \\
\hline Age (years) & $54(35-76)$ & $57(44-77)$ & 0.231 \\
\hline Male/female & $40 / 22$ & $33 / 29$ & 0.205 \\
\hline $\begin{array}{ll}\text { Left ventricular } & \text { ejection } \\
\text { fraction (\%) } & \end{array}$ & $59.9 \pm 3.5$ & $59.8 \pm 2.7$ & 0.908 \\
\hline Heart rate & 75 (64-100) & $76(62-107)$ & 0.617 \\
\hline Systolic Blood Pressure $(\mathrm{mmHg})$ & $120(108-140)$ & $125(90-138)$ & 0.146 \\
\hline \begin{tabular}{|lll} 
Diastolic & Blood & Pressure \\
$(\mathrm{mmHg})$ & & \\
\end{tabular} & $70(60-82)$ & $76(60-90)$ & 0.277 \\
\hline Hemoglobin A1c (\%) & 7.1 (4.9-10.4) & $6.7(6.0-10.6)$ & 0.816 \\
\hline Body Mass Index & $\begin{array}{|ll|}27.6 & (21.2- \\
39.8) & \\
\end{array}$ & $\begin{array}{ll}31.0 & (20.1- \\
39.3) & \end{array}$ & 0.136 \\
\hline
\end{tabular}

The PDW (17.7\% [range: 15.9-19.5\%] vs. $17.4 \%$ [range: $16.2-18.9 \%$ ]; $p=0.047)$, MPV (8.3 [range: 6.6-11.4] vs. 7.5 [range: 6.6-8.7] Fl; $\mathrm{p}<0.001)$, PCT (0.2 [range: $0.16-0.25$ ] vs. 0.18 [range: 0.13-0.24]; $p=0.004)$, and the neutrophil-lymphocyte ratio (NLR; 1.71 [range: $0.82-9.14$ ] vs. 1.43 [range: $0.78-5.75$ ]; $p=0.036$ ) were significantly higher in MB patients than they were in the control group. However, there were no significant differences among the groups in terms of other biochemical and hemogram values. (Table II).
Table II: Laboratory data of study groups

\begin{tabular}{|c|c|c|c|}
\hline & $\begin{array}{c}\text { Diabetic } \\
\text { Myocardial Bridge } \\
\text { Group }(n=62)\end{array}$ & $\begin{array}{l}\text { Control } \\
(n=62)\end{array}$ & $\mathrm{p}$ \\
\hline \multicolumn{4}{|c|}{ MEDIAN (Min-Max.) } \\
\hline LDL-cholesterol (mg/dL) & $109.2(37.8-189.7)$ & $123.2(72-210.9)$ & 0.051 \\
\hline Triglyceride (mg/dL) & $146.5(66-634)$ & $158.5(70-548$ & 0.932 \\
\hline Total cholesterol (mg/dL) & $195(91-293)$ & $211(97.6-395)$ & 0.352 \\
\hline HDL-cholesterol (mg/dL) & $42.9(22.8-86.1)$ & $46.6(27.3-72.5)$ & 0.900 \\
\hline GFR(\%) & $85.1(60-118.3)$ & $89.6(55-120)$ & 0.133 \\
\hline $\mathrm{ALT}(\mathrm{u} / \mathrm{l})$ & $22.5(8-51)$ & $20(12-55)$ & 0.216 \\
\hline AST $(u / l)$ & $21(13-97)$ & $22(7-48)$ & 0.233 \\
\hline $\mathrm{TSH}$ & $1.23(0.3-3.9)$ & $1.6(0.3-4.21)$ & 0.455 \\
\hline CRP (mg/L) & $0.83(0.01-5)$ & $1.54(0.1-7.6)$ & 0.354 \\
\hline WBC, $\left(\mathrm{u} / \mathrm{mm}^{3}\right)$ & $7.5(4.3-12.8)$ & $7.4(4.5-12.9)$ & 0.434 \\
\hline Hemoglobin (gr/dL) & $14.7(10.6-17.5)$ & $13.8(9.6-19.8)$ & 0.114 \\
\hline MCV & $86.6(64.6-96.7)$ & $86.4(79-94)$ & 0.472 \\
\hline RDW (\%) & $15.2(14.1-16.8)$ & $15.3(12.8-16.8)$ & 0.659 \\
\hline Neutrophil, $\left(\mathrm{u} / \mathrm{mm}^{3}\right)$ & $4.1(2.0-9.3$ & $3.9(0.02-8.0)$ & 0.065 \\
\hline Lymphocyte, $\left(\mathrm{u} / \mathrm{mm}^{3}\right)$ & $2.4(0.8-4.6)$ & $2.7(0.01-4,0)$ & 0.369 \\
\hline Monocyte, $\left(\mathrm{u} / \mathrm{mm}^{3}\right)$ & $0.6(0.01-0.9)$ & $0.5(0.2-4.3)$ & 0.487 \\
\hline Basophils, $\left(\mathrm{u} / \mathrm{mm}^{3}\right)$ & $0.07(0.01-0.16)$ & $0.07(0.01-0.21)$ & 0.568 \\
\hline Eosinophil, $\left(\mathrm{u} / \mathrm{mm}^{3}\right)$ & $0.13(0.01-1.38)$ & $0.16(0.03-0.82)$ & 0.899 \\
\hline $\begin{array}{lll}\text { Platelet } & \text { counts } & \text { (PIt) } \\
\left(\mathrm{k} / \mathrm{mm}^{3}\right) & & \\
\end{array}$ & 243 (178-333) & 241.5 (163-362) & 0.536 \\
\hline PDW (\%) & 17.7 (15.9-19.5) & $17.4(16.2-18.9)$ & 0.047 \\
\hline MPV (FI) & $8.3(6.6-11.4)$ & $7.5(6.6-8.7)$ & $<0.001$ \\
\hline PCT & $0.2(0.16-0.25)$ & $0.18(0.13-0.24)$ & 0.004 \\
\hline $\begin{array}{l}\text { Neutrophil Lymphocyte } \\
\text { Ratio (NLR) }\end{array}$ & $1.71(0.82-9.14)$ & $1.43(0.78-5.75)$ & 0.036 \\
\hline $\begin{array}{l}\text { Platelet } \quad \text { Lymphocyte } \\
\text { Rate (PLR) }\end{array}$ & $106(63.5-252.1)$ & $\begin{array}{ll}85.6 & (60.5- \\
40857.1) & \end{array}$ & 0.161 \\
\hline
\end{tabular}

LDL: low-density lipoprotein, HDL: high-density lipoprotein, GFR: glomerular filtration rate, ALT: alanine aminotransferase, AST: aspartate aminotransferase, TSH: Thyroid-stimulating hormone, CRP: $C$ reactive protein, WBC: White blood count, MCV: Mean Corpuscular Volume, 
RDW: Red cell distribution width, PDW: Platelet distribution width, MPV: Mean platelet volume, PCT: plateletcrit.

\section{DISCUSSION}

To our knowledge, this is the first study to investigate platelet indices in diabetic patients with MB. The PDW, MPV, and PCT values were significantly higher in diabetic patients with $\mathrm{MB}$ than they were in the control group participants. Our findings also showed an increase in the index and activation of platelets in diabetic MB patients. The frequency of MB on coronary angiography was $5.2 \%$ in our study, while the prevalence of MB in diabetic patients was $1.7 \%$. MB is a risk factor for coronary atherosclerosis ${ }^{13}$ and has been reported to trigger the development of coronary atherosclerosis, especially in elderly DM patients ${ }^{13}$.

Changes in endothelial cell morphology occur due to the shear stress of blood flow both before and after the bridge segment ${ }^{18}$ because MB changes the hemodynamics of coronary flow. Any alteration in coronary flow hemodynamics may lead to endothelial dysfunction, which causes atherosclerosis ${ }^{19}$ by promoting various harmful abnormalities in arterial vessels, including vasoconstriction, inflammation, and thrombosis ${ }^{20}$. Studies have shown that DM causes endothelial dysfunction ${ }^{21}$. It has also been reported that chronic inflammation plays an important role in the pathogenesis of many chronic diseases, such as $\mathrm{DM}^{22}$. The coexistence of endothelial dysfunction and chronic inflammation may accelerate atherosclerosis with a synergistic effect.

The NLR is currently being evaluated as a new marker of inflammation; it has been suggested as a new biomarker of cardiovascular events and prognosis ${ }^{23}$. In our study, this parameter was elevated in MB patients. Platelets also play a major role in the pathogenesis of atherothrombosis ${ }^{24}$. Platelet indices are platelet activation markers and may help in the diagnosis and prognosis of many diseases, including CVD ${ }^{25}$. An increase in the MPV and PDW values in diabetic patients is thought to be related to the incidence of diabetic vascular complications ${ }^{26}$.

The platelet indices are practical, cheap, and readily accessible parameters that can be easily estimated by a complete blood count and are associated with a range of medical conditions and pathologies 27 . The platelet size reflects platelet activity and is measured using the $\mathrm{MPV}^{28}$. Large platelets have higher reactivity and produce more prothrombotic factors ${ }^{29}$.

\section{Study limitations}

Retrospective design is the most important limitation of this study.

\section{CONCLUSIONS}

Our findings showed an increase in the PDW, MPV, and PCT platelet indices in diabetic MB patients. Routine hematological analyses are important, simple, effortless, and cost-effective tests that may be predictive of MB. Future prospective large-scale, randomized controlled trials will be required to confirm our findings.

Ethics Committee Approval: The study was conducted in accordance with the ethical approval of the University Ethics Committee. (Date: 14/10/2019 Decision number: 2019/218).

Declaration of Conflicting Interests: The authors declare that they have no conflict of interest.

Financial Disclosure: No financial support was received.

\section{REFERENCES}

1. Rogers IS, Tremmel JA, Schnittger I. Myocardial bridges: Overview of diagnosis and management. Congenit Heart Dis. 2017; 12: 619-23.

2. De Giorgio F, Grassi VM, Polacco M, et al. Myocardial bridging and sudden cardiac death: is 
the actual classification exhaustive? Int J Cardiol.. 2014;172:e383-e4.

3. Tsujita K, Maehara A, Mintz GS, et al. Comparison of angiographic and intravascular ultrasonic detection of myocardial bridging of the left anterior descending coronary artery. Am J Cardiol. 2008; 102: 1608-13.

4. Reyman HC. Dissertatio de vasis cordis propriis. Bibl Anat. 1737; 2: 359-78.

5. Podolec J, Siudak Z, Malinowski K et al. Prevalence and clinical presentation of myocardial bridge on the basis of the National Polish Percutaneous Interventions Registry and the Classification of Rare Cardiovascular Diseases. Kardiol Pol. 2018; 77: 46570.

6. Möhlenkamp S, Hort W, Ge J, et al. Update on myocardial bridging. Circulation. 2002; 106: 261622.

7. Corban MT, Hung OY, Eshtehardi $\mathrm{P}$ et al. Myocardial bridging: contemporary understanding of pathophysiology with implications for diagnostic and therapeutic strategies. J Am Coll Cardiol. 2014; 63: 2346-55.

8. Herrmann J, Higano ST, Lenon RJ, et al. Myocardial bridging is associated with alteration in coronary vasoreactivity. Eur Heart J. 2004; 25: 2134-42.

9. Ge J, Jeremias A, Rupp A et al. New signs characteristic of myocardial bridging demonstrated by intracoronary ultrasound and Doppler. Eur Heart J. 1999; 20: 1707-16.

10. Ogurtsova K, da Rocha Fernandes J, Huang Y et al. IDF Diabetes Atlas: Global estimates for the prevalence of diabetes for 2015 and 2040. Diabetes Res Clin Pract. 2017; 128: 40-50.

11. Villano A, Mencarelli E, Melita V et al. Endothelial dysfunction and cardiovascular outcome in asymptomatic patients with type 2 diabetes: A pilot study. Diabetes Metab Res Rev. 2020; 36: e3215.

12. Di Angelantonio E, Kaptoge S, Wormser D et al. Association of cardiometabolic multimorbidity with mortality. JAMA. 2015; 314: 52-60.

13. Nakaura T, Nagayoshi Y, Awai K et al. Myocardial bridging is associated with coronary atherosclerosis in the segment proximal to the site of bridging. J Cardiol. 2014; 63: 134-9.

14. Haybar H, Khodadi E, Zibara K, et al. Platelet activation polymorphisms in ischemia. Cardiovasc Hematol Disord Drug Targets. 2018; 18: 153-61.

15. Gary T, Pichler M, Belaj $\mathrm{K}$, et al. Platelet-tolymphocyte ratio: a novel marker for critical limb ischemia in peripheral arterial occlusive disease patients. PLoS One. 2013; 8 :e67688.

16. Wiwanitkit V. Plateletcrit, mean platelet volume, platelet distribution width: its expected values and correlation with parallel red blood cell parameters. Clin Appl Thromb Hemost. 2004; 10: 175-8.

17. Erhart S, Beer JH, Reinhart WH. Influence of aspirin on platelet count and volume in humans. Acta Haematol. 1999; 101: 140-4.

18. Bourassa MG, Butnaru A, Lespérance J, et al. Symptomatic myocardial bridges: overview of ischemic mechanisms and current diagnostic and treatment strategies. J Am Coll Cardiol. 2003; 41: 351-9.

19. Sitia S, Tomasoni L, Atzeni $\mathrm{F}$ et al. From endothelial dysfunction to atherosclerosis. Autoimmun Rev. 2010; 9: 830-4.

20. Münzel T, Daiber A, Ullrich V, et al. Vascular consequences of endothelial nitric oxide synthase uncoupling for the activity and expression of the soluble guanylyl cyclase and the cGMP-dependent protein kinase. Arterioscler Thromb Vasc Biol. 2005; 25: 1551-7.

21. Ho HCH, Maddaloni E, Buzzetti R. Risk factors and predictive biomarkers of early cardiovascular disease in obese youth. Diabetes Metab Res Rev. 2019; 35: e3134.

22. Bell DS, O'Keefe JH. White cell count, mortality, and metabolic syndrome in the Baltimore longitudinal study of aging. J Am Coll Cardiol. 2007; 50: 1810 .

23. Guasti L, Dentali F, Castiglioni L, et al. Neutrophils and clinical outcomes in patients with acute coronary syndromes and/or cardiac revascularisation. A systematic review on more than 34,000 subjects. Thromb Haemost. 2011; 106: 5919. 
24. Agrawal J, Singh VB, Meena B, et al. Mean paltelet volume (MPV) the neglected marker of cardiovascular risk and glycosylated hemoglobin in diabetic patient. Diabetes Metab Syndr. 2017; 11: 109-12.

25. Sansanayudh N, Anothaisintawee T, Muntham D, et al. Mean platelet volume and coronary artery disease: a systematic review and meta-analysis. Int J Cardiol. 2014; 175: 433-40.

26. Jindal S, Gupta S, Gupta R et al. Platelet indices in diabetes mellitus: indicators of diabetic microvascular complications. Hematology. 2011; 16: 86-9.
27. Tulgar Y, Cakar S, Tulgar S, et al. The effect of smoking on neutrophil/lymphocyte and platelet/lymphocyte ratio and platelet indices: a retrospective study. Eur Rev Med Pharmacol Sci. 2016; 20: 3112-8.

28. Park Y, Schoene N, Harris W. Mean platelet volume as an indicator of platelet activation: methodological issues. Platelets. 2002; 13: 301-6.

29. Jakubowski JA, Thompson CB, Vaillancourt R, et al. Arachidonic acid metabolism by platelets of differing size. Br J Haematol. 1983; 53: 503-11. 